\title{
VPLYV ZMENY KLÍMY NA EFEKTÍVNOSŤ EPC PROJEKTOV
}

\author{
THE IMPACT OF CLIMATE CHANGE ON THE EFFECTIVENNES OF EPC \\ PROJECTS
}

\author{
Veronika Klincová, ${ }^{*}, 1$
}

*veronika.klincova@stuba.sk, veronika.klincova@gmail.com

${ }^{2}$ Slovenská technická univerzita v Bratislave, Stavebná fakulta, Radlinského 2766/11, 81005 Bratislava

\begin{abstract}
Abstrakt
Spotreba energie v budovách je dôležitým faktorom súvisiacim s trvalo udržatel'ným rozvojom a je úzko spojená s hlavnou hrozbou l’udskej spoločnosti, ktorú predstavuje tvorba skleníkových plynov a s tým súvisiace globálne otepl'ovanie. Optimalizácia spotreby energie v budovách a efektívne využívanie energie z obnovitel'ných zdrojov energie s minimálnym dopadom na životné prostredie predstavujú jadro boja proti zmene podnebia. Článok pojednáva o problematike súčasného stavu klimatických zmien a ich dopadu na spotrebu energie v budove, popisuje možnosti hodnotenia EHB prostredníctvom simulácií ako nástroja pre optimálny návrh spotreby energie so zohl'adnením údajov o budúcej klíme a zároveň objasňuje model financovania zlepšenia energetickej efektívnosti budov prostredníctvom EPC projektov.
\end{abstract}

\section{Kl’účové slová}

Zmena klímy, energetická hospodárnost', EPC projekt, energetická simulácia

\begin{abstract}
Energy consumption in buildings is an important factor related to sustainable development and is closely linked to the main threat to human society posed by greenhouse gas emissions and the associated global warming. Optimizing of energy consumption in buildings and the efficient use of energy from renewable sources with minimal impact on the environment are at the heart of the fight against climate change. The article discusses the current state of climate change and its impact on energy consumption in the building, describes the possibilities of assessing the future energy performance of buildings through simulations as a tool for optimal design of energy consumption in a building, taking into account future climate data, and explains the financing model for improving energy efficiency of buildings through EPC projects.
\end{abstract}

\section{Key words}

Climate change, energy efficiency, EPC project, energy simulation

\section{1 ÚVOD}

Stavebný sektor je jeden z najväčších spotrebitel'ov energie, pričom sa odhaduje, že budovy po celom svete sú zodpovedné za viac ako 40 \% celkovej spotreby primárnej energie a s tým súvisiacou tvorbou skleníkových plynov [1]. Väčšina budov sa v súčasnosti navrhuje tak, aby vydržala viac ako 50 rokov, pričom budovy ako súčast' infraštruktúry musia dlhodobo odolávat' meniacim sa klimatickým podmienkam. Pri návrhu treba brat' do úvahy, že budovy budú vystavené klíme, ktorá bude postupne teplejšia a preto je potrebné zabezpečit', aby súčasné aj budúce stavby spol'ahlivo pracovali za meniacich sa klimatických podmienok. Niekol'ko súčasných štúdií predpokladá budúci nárast ročného dopytu po chladení a pokles ročného dopytu po vykurovaní [2]. Zmena klímy predstavuje výzvu pre projektanta budovy, najskôr preto, že dlhodobým ciel'om svetového spoločenstva je znížit' využívanie energie s ciel'om obmedzit' rozsah budúcich klimatických zmien spôsobených l'udskou činnost'ou.

Investícia do zlepšenia energetickej účinnosti budov poskytuje okrem zníženia dopadu na zmenu podnebia aj okamžitý pozitívny peňažný tok vyplývajúci z nižších účtov za energiu. Okrem obvyklých možností financovania, ktoré majú vlastníci a prevádzkovatelia budov (napríklad formou pôžičky alebo úveru), sú k dispozícii aj iné spôsoby financovania takýchto projektov. Jednou z týchto metód je financovanie prostredníctvom EPC projektu. 


\section{KLIMATICKÉ ZMENY A STAVEBNÝ SEKTOR}

Podnebie Zeme sa v priebehu histórie menilo. Zvláštny význam je potrebné venovat' predovšetkým súčasnému trendu otepl'ovania planéty, ktorý je výsledkom l’udskej činnosti približne od polovice 20. storočia a ktorá postupuje rýchlost'ou, ktorá je neudržatel'ná. Za hlavnú príčinu klimatických zmien sa považuje globálne otepl'ovanie, ktoré je spôsobené skleníkovým efektom [3].

\section{Skleníkové plyny a spotreba energie v stavebnom sektore}

Emisie skleníkových plynov zo stavebného sektoru sa v období od roku 1970 viac ako zdvojnásobili, čo vo výsledku znamená viac ako 19 \% všetkých globálnych emisií skleníkových plynov z roku 2010. Väčšina týchto emisií sú nepriame emisie, ktoré vznikajú využívaním elektrickej energie v budovách, a ktoré počas sledovaného obdobia rástli na rozdiel od priamych emisií, ktoré sa vyznačovali stagnáciou (Obr. 1) [4].

Vzhl'adom na fakt, že v stavebnom sektore je vysoký podiel nepriamych emisií, skutočné hodnoty závisia vo vel'kej miere od výroby a spotreby energie. V roku 2010 spotrebovali budovy až 32 \% celkovej globálnej konečnej energie, pričom na vykurovanie budov (bytových aj komerčných) bolo potrebných 32-34 \% z tohto podielu. Ďalším významným spotrebitel’om v komerčných budovách bolo osvetlenie, zatial' čo v obytných budovách to bolo varenie a príprava TÚV (Obr.1) [4].

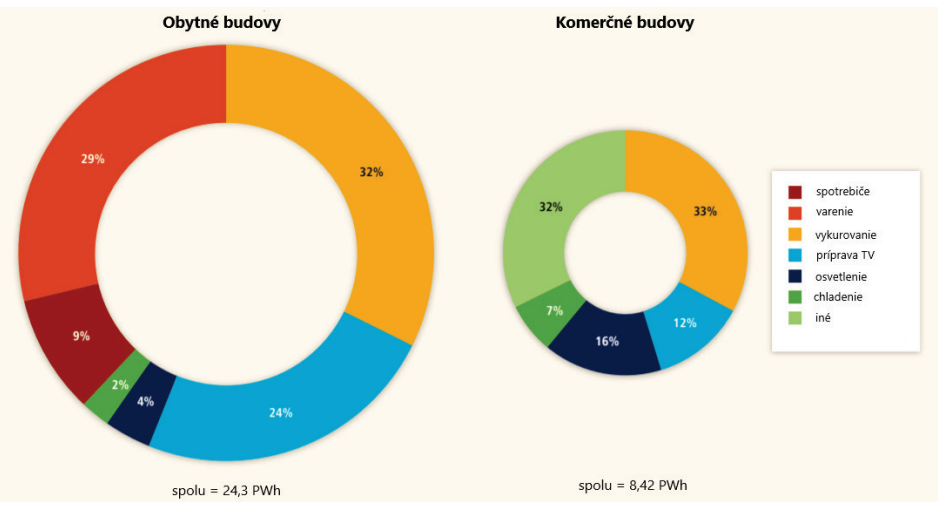

Obr. 1 Svetová konečná spotreba energie v budovách podl’a konečného použitia v roku 2010.

\section{Prognózy zmeny klímy - klimatické scenáre}

Prognózy budúceho vývoja klímy predpovedajú tzv. Reprezentatívne koncentračné scenáre - RCP. Tieto scenáre sú založené na sociálno-ekonomických, technologických a energetických predpokladoch, predpokladoch využívania pôdy, tvorbe emisií skleníkových plynov a úrovne znečistenia ovzdušia [2]. Existujú 4 základné klimatické scenáre v závislosti od emisných scenárov tvorby antropogenného skleníkového plynu, pričom opisujú varianty otepl'ovania zväčša do roku 2100 (Obr. 2). RCP 4.5 je tzv. stabilizačný scenár, ktorý počíta s tým, že koncentrácia $\mathrm{CO}_{2}$ bude kumulovat' okolo roku 2050 a stabilizuje sa po roku 2100 okolo hodnoty 520 ppm, pričom priemerná teplota vzduchu sa do roku 2100 zvýši o $1,8{ }^{\circ} \mathrm{C}$ [5]. Menej optimistický scenár RCP 8.5 predpokladá zvýšenie teploty o $4,9^{\circ} \mathrm{C}$ alebo viac do roku 2100 v porovnaní s obdobím pred revolúciou, sprevádzané zvýšením extrémnych teplotných udalostí [2]. Okrem toho predpovedá zvýšenie emisií $\mathrm{CO}_{2}$ až na úroveň $950 \mathrm{ppm} \mathrm{v}$ roku 2100, pričom očakáva, že d'alší rast bude prebiehat' minimálne do roku 2200 [5].

\section{Vlna renovácie v stavebnom sektore}

Európska komisia vo svojom oznámení o Európskej zelenej dohode informuje, že stavba, jej použivanie a obnova budov sú zodpovedné za 40 \% spotrebovanej energie v EÚ [6]. Na splnenie ciel’a znížit' emisie skleníkových plynov o 55 \% sa môžu pričinit' práve budovy a výroba elektrickej energie. Hlavným ciel'om je v čo najväčšej miere zavádzat' výrobu energie z obnovitel'ných zdrojov energie, pričom podiel výroby elektriny z obnovitel'ných zdrojov sa má do roku 2030 minimálne zdvojnásobit' - zo súčasných $32 \%$ na $65 \%$ a viac. Využívaním energie z obnovitel'ných zdrojov sa významne dekarbonizujú mnohé odvetvia, napr. chladenie a vykurovanie v budovách 
a priemysle. Dôležité je, aby úroveň využívania obnovitel’ných zdrojov energie pri vykurovaní a chladení dosiahla aspoň $40 \%$ [7].

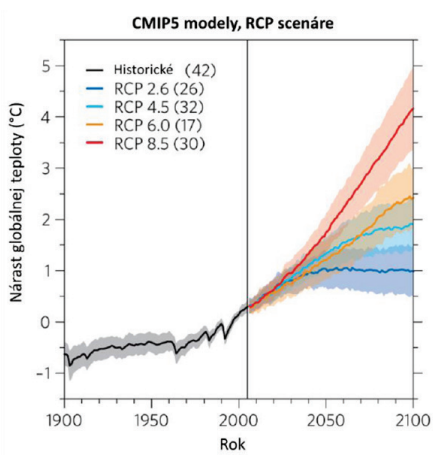

Obr. 2 Prognózy globálneho oteplenia povrchu Zeme podl’a klimatických scenárov vzhl’adom k obdobiu

1986-2005.

Až 75\% budov v rámci EÚ je energeticky nehospodárnych a napr. na vykurovanie používa zastarané systémy využívajúce fosílne palivá, uhlie alebo ropu [7]. Ročná miera renovácie fondu budov sa pritom v členských štátoch pohybuje len na úrovni od 0,4 do 1,2\%. Iniciatívou EÚ je zapojit'sa do vlny renovácie verejných aj súkromných budov, čo má za ciel' znížit účty za energie a zároveň aj energetickú chudobu. Renováciu verejných a súkromných budov je v rámci Európskej zelenej dohody označená ako klúčová iniciatíva na zlepšenie energetickej efektívnosti v stavebnom sektore. Do roku 2030 má byt' obnovených až 35 miliónov budov [6].

$\mathrm{Na}$ dosiahnutie európskych ciel'ov v oblasti energetiky a klímy do roku 2030 bude potrebných približne 275 miliárd ročne, preto je okrem verejného financovania potrebné odblokovat' aj súkromné financovanie. Európska komisia vytvorila iniciatívu Inteligentné financovanie inteligentných budov, ktorá slúži na mobilizáciu súkromného financovania energetickej účinnosti a obnovitel'ných zdrojov energie [8]. Iniciatíva Inteligentné financovanie inteligentných budov podporuje aj využívanie tzv. zmlúv o energetickej hospodárnosti (EPC projekty), ktoré môžu byt' východiskovým riešením pri obnove budov, ktorých majitel' nemá počiatočný kapitál na obnovu.

\section{EPC PROJEKTY}

Metóda EPC ponúka realizáciu úsporných opatrení v energetickom hospodárstve vrátane zabezpečenia finančných zdrojov prostredníctvom splácania investície z dosiahnutých a dodávatel’om zaručených úspor, tzn. bez nutnosti investície zo strany zákazníka, vlastníka a prevádzkovatel’a objektu.

EPC je obchodný model, ktorý zakladá zmluva o energetickej efektívnosti. Zmluvou o energetickej efektívnosti je zmluva uzatvorená medzi poskytovatel'om garantovanej energetickej služby a prijímatel'om garantovanej energetickej služby, na základe ktorej je poskytovatel'ovi garantovanej energetickej služby odplata za poskytnuté služby uhrádzaná podl'a toho, či skutočne dosiahol zmluvne určené hodnoty zlepšenia energetickej efektívnosti [9]. V zmysle zákona č.321/2014 Z.z. ide o energetickej efektívnosti ide o garantovanú energetickú službu. Pri EPC sa uskutočňuje modernizácia objektov a zariadení prijímatel’a služby, ktorá vedie k zníženiu nákladov na spotrebu energií a súvisiacich prevádzkových nákladov. Náklady na modernizáciu, ktorú podl’a potrieb prijímatel'a navrhne, naprojektuje, realizuje a prefinancuje poskytovatel', sa splácajú z v budúcnosti dosahovaných úspor, za ktoré sa poskytovatel' služby zaručí. Poskytovatel' služby počas obdobia splácania modernizácie poskytuje energetický manažment a vyhodnocuje dosahované úspory. V prípade, že by nastal výpadok úspor, zaväzuje sa poskytovatel' uhradit' prijímatel'ovi služby finančnú hodnotu výpadku úspor.

Pri modernizácii budov sa EPC zmluva dotýka alebo jednotlivej budovy alebo súboru budov rôzne umiestnených nie vo vzájomnej/ bezprostrednej blízkosti, (napr. školy v meste, rozličné budovy VúC, ret'azec obchodov, kancelárií) alebo viacerých budov teritoriálne a funkcionálne súvisiacich a prepojených (napr. nemocnica, výrobný podnik). Modernizuje sa energetická infraštruktúra a stavebná obálka budov. Objektom modernizácie sú systémy vykurovania a vzduchotechniky, vnútorného a vonkajšieho osvetlenia, rozvodov energie, rekuperácie, kotly, solárne zdroje, fotovoltika, tepelné čerpadlá, kogenerácie, trigenerácie, príprava pitnej aj bazénovej vody, technológia práčovne, automatizácia energetického manažmentu a aplikácia výhodnejšieho odberového diagramu, výmena okien, oprava stavebných otvorov a striech a i. [10]. 
Návratnost' projektov EPC je typicky 6 až 10 rokov, ale realizovali sa projekty s kratšou aj dlhšou dobou návratnosti. Krátkodobo návratné projekty sa uskutočňujú v prípade, ked' sa podarí objavit' významnú optimalizačnú príležitost', ktorú prijímatel' nemal možnost' financovat' (alebo to nebola jeho priorita), alebo ju jednoducho neodhalil. Dlhodobo návratné projekty sú typické vel'kým podielom drahých modernizačných opatrení, ktoré nemajú rýchlu finančnú návratnost’ z budúcich úspor energie - napr. niektoré typy stavebných úprav budov.

\section{ENERGETICKÉ SIMULÁCIE BUDOV - JEDNODUCHÁ SIMULÁCIA ADMINISTRATIIVNEJ BUDOVY}

Simulácie energetickej hospodárnosti budov sa stali ústredným prvkom pri navrhovaní a optimalizácii energetických systémov budov. Slúžia ako podporný nástroj na zistenie energetickej náročnosti budovy a dokážu nájst' optimalizačné opatrenia v budove tak, aby po jej obnove vedel byt' EPC projekt efektívny a úspešný. Energetické modely môžu posúdit' rôzne konštrukcie, technické systémy a prevádzky, s ciel'om určit' najvhodnejší návrh s najvhodnejšou celkovou energetickou hospodárnost’ou. Vd’aka dopytu po ekologických budovách je aplikácia simulácie budov v dnešnej dobe skôr nevyhnutnost’ou ako potrebou. Energetické simulácie sú teda dôležitou súčast'ou štúdií o zmene klímy ako prostriedok pre predikciu dopytu budov po energii v rámci zmeny klímy a majú vel'ký význam pre úsporu energie v budovách.

Pre posúdenie vplyvu zmeny klímy na energetický koncept administratívnej budovy bola vykonaná jednoduchá energetická simulácia.

\section{Opis modelu a vstupné dáta}

Simulovaný objekt je nepodpivničená dvojpodlažná administratívna budova splochou strechou. Jedná sa o samostatne stojaci objekt umiestnený v rovinatom teréne $\mathrm{v}$ katastrálnom území mesta Bratislava, z čoho vyplývajú aj okrajové podmienky vonkajšej klímy. Hodinové údaje o počasí sú zostavené z meraní v lokalite Bratislava-letisko.

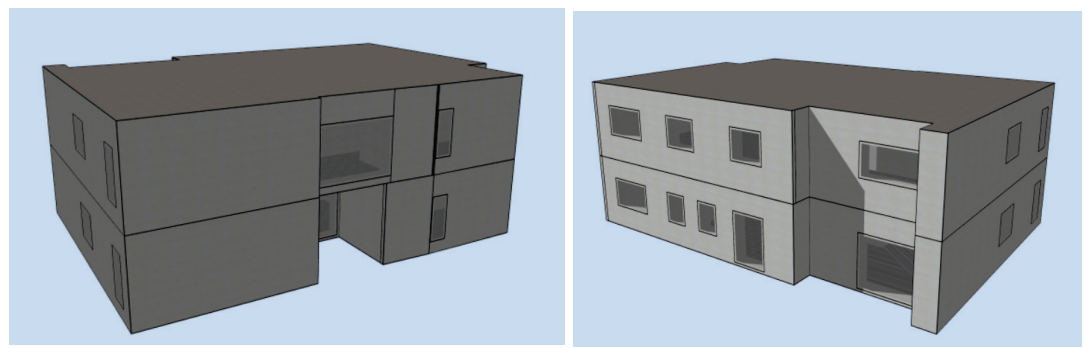

Obr. 3 3D geometria modelu z programu DesignBuilder

Pre vytvorenie modelu administratívnej budovy bol použitý softvér DesignBuilder, samotná simulácia a výpočet bol zrealizovaný pomocou programu EnergyPlus. Pri vytváraní simulácie bolo zohl'adňované prostredie, v ktorom je budova osadená, orientácia na svetové strany, charakteristiky vnútorných a vonkajších obalových konštrukcií, systém vykurovania, chladenia, spôsob infiltrácie vzduchu a vetrania. Pre jednotlivé miestnosti boli podl'a ich účelu spracované harmonogramy obsadeností miestností l'ud'mi, harmonogramy využívania osvetlenia a elektrických spotrebičov.

Budova bola vytvorená v dvoch variantoch:

- Pôvodný stav - uvažovalo sa s budovou, ktorej obvodový plášt' prešiel rekonštrukciou pred 20-25 rokmi, t.j. murovaná obvodová stena zateplená tepelnou izoláciou hrúbky $50 \mathrm{~mm}$, strecha zateplená izoláciou hrúbky $100 \mathrm{~mm}$, plastové okná s izolačným dvojsklom. V budove bol uvažovaný systém vykurovania a prípravy teplej vody plynovým kotlom a systém prirodzeného vetrania. V budove sa neuvažovalo so systémom chladenia.

- Nový stav - skladby obalových konštrukcií boli navrhnuté/ obnovené tak, aby spĺn̆ali súčasné odporúčané hodnoty tepelného odporu podl'a normy STN 730540-2- Z1. V budove bol uvažovaný systém vykurovania, chladenia, prípravy teplej vody a núteného vetrania prostredníctvom tepelného čerpadla vzduch-voda a systém úsporného osvetlenia. 
Tab. 1 Vybrané vstupné údaje pre simuláciu podl’a kategórií programu DesignBuilder.

\begin{tabular}{|c|c|c|c|}
\hline Kategória & Vstupný údaj & Pôvodný stav & Nový stav \\
\hline Vnút. zat’aženie & Obsadenost' & 0,167 l’udí/m² & 0,167 l'udí/m² \\
\hline Vnút. zat'aženie & Metabolická produkcia tepla na osobu & $130 \mathrm{~W} /$ osobu & $130 \mathrm{~W} /$ osobu \\
\hline Vnút. zat'aženie & Generovanie $\mathrm{CO}_{2}$ & 0,0000000382 & $0,0000000382\left(\mathrm{~m}^{3} / \mathrm{s} . \mathrm{W}\right)$ \\
\hline Vnút. zat'aženie & Potreba teplej vody & $0,200\left(1 / \mathrm{m}^{2} \cdot\right.$ deň $)$ & $0,200\left(1 / m^{2}\right.$. deň $)$ \\
\hline Vnút. zat'aženie & Vykurovacia teplota & $20^{\circ} \mathrm{C}$ & $20^{\circ} \mathrm{C}$ \\
\hline Vnút. zat'aženie & Temperovacia teplota & $15^{\circ} \mathrm{C}$ & $15^{\circ} \mathrm{C}$ \\
\hline Vnút. zat’aženie & Vnút. teplota chladenia & - & $26^{\circ} \mathrm{C}$ \\
\hline Vnút. zat'aženie & Min. teplota, pri kt. sa prirodzene vetrá & $24^{\circ} \mathrm{C}$ & - \\
\hline Vnút. zat'aženie & Množstvo čerstvého vzduchu na osobu & 14 1/s.osoba & 14 1/s.osoba \\
\hline Osvetlenie & Typ osvetlenia & Pôvodné & Úsporné LED osvetlenie \\
\hline Otvory - okná & Zasklenie - $\mathrm{U}_{\mathrm{g}}$ & $1,667 \mathrm{~W} / \mathrm{m}^{2} . \mathrm{K}$ & $0,963 \mathrm{~W} / \mathrm{m}^{2} \cdot \mathrm{K}$ \\
\hline Otvory - okná & $\begin{array}{c}\text { Zasklenie - priepustnost' energie } \\
\text { slnečného žiarenia - g }\end{array}$ & 0,642 & 0,485 \\
\hline Otvory - okná & Zasklenie - činitel' prestupu svetla & 0,682 & 0,71 \\
\hline Otvory - okná & Rám-U $\mathrm{f}_{\mathrm{f}}$ & $2,1 \mathrm{~W} / \mathrm{m}^{2} \cdot \mathrm{K}$ & $1,149 \mathrm{~W} / \mathrm{m}^{2} . \mathrm{K}$ \\
\hline Otvory - okná & Tienenie & $\mathrm{Nie}$ & $\mathrm{Nie}$ \\
\hline Konštrukcie & Infiltrácia & $11 / \mathrm{h}$ & $0,11 / \mathrm{h}$ \\
\hline
\end{tabular}

\section{Generovanie budúcich údajov o počasí}

EnergyPlus ako výpočtový program pre energetickú simuláciu vyžaduje údaje o počasí za jeden rok, ktorý reprezentuje klímu v mieste budovy, pričom používané súbory počasia sa obvykle zakladajú na historických environmentálnych záznamoch, ktoré predstavujú priemerné klimatické roky. Vzhl'adom na rozsah klimatických zmien a ich vplyv na požiadavky na vykurovanie a chladenie budov však simulácie využívajúce hodinové súbory TRKR nedokážu predpovedat' trendy dopytu po energii v budovách budúcnosti. V dôsledku toho bolo vyvinutých niekol'ko metód na generovanie budúceho súboru informácií o počasí pre energetické simulácie budov.

Súbor budúcich údajov o počasí pre účely tejto energetickej simulácie bol zostavený tzv. metódou morfovania. Východiskovým bodom tejto metódy je súbor údajov o počasí s vysokým rozlíšením pre dané miesto. Tieto údaje sa potom upravia pomocou predpovedí z globálneho alebo regionálneho klimatického modelu, čo vedie k zmenám priemerných mesačných hodnôt premenných počasia [11]. Z databázy programu DesignBuilder bol prebraný bežne dostupný súbor pre energetickú simuláciu pre lokalitu Bratislava-letisko, ktorý bol použitý ako východiskový súbor údajov o počasí reprezentujúci súčasnú klímu. Tento bol následne morfovaný využitím nástroja - generátora počasia CCWorldWeatherGen. Z databázy IPCC boli stiahnuté HadCM3 klimatické scenáre, ktoré boli následne použité pre vytvorenie budúcich údajov o počasí. Morfovaný klimatický rok bol vygenerovaný na základe klimatického scenára A2 pre obdobie 2050. Emisný scenár A2 je jeden z „markerových“ scenárov vypracovaných prostredníctvom IPCC a je to bežný scenár využívaný pri energetických simuláciách. Scenár A2 je na hornom konci emisných scenárov SRES. Dejová línia A2 sa vyznačuje heterogenitou. Zdôrazňuje sa sebadôvera a miestna identita a populácia sa neustále zvyšuje. Obyvatel'stvo do roku 2050 dosiahne viac ako 10 miliárd. Ekonomický rozvoj je regionálne zameraný a ekonomický a technologický rozvoj je v porovnaní s ostatnými dejovými líniami pomerne pomalý. Predpokladá, že v 21. storočí rýchlo rastie množstvo metánu a oxidu dusného. Oxid uhličitý stúpa na maximálnu hodnotu tesne pred rokom 2100 [12].

\section{CIEL A VÝSLEDKY}

Hlavným ciel'om simulácie bolo zistit' a porovnat' ročnú spotrebu energie administratívnej budovy v pôvodnom a v obnovenom stave pri uvažovaní súčasných aj budúcich klimatických podmienok, zohl’adňujúcich zmenu klímy (pre rok 2050).

Pre pôvodný aj obnovený stav boli uvažované 2 varianty referenčného klimatického roku a to referenčný klimatický rok súčasnej klímy a referenčný klimatický rok budúcej klímy podl'a klimatického scenára A2 (rok 2050).V prípade referenčného roka súčasnej klímy je ročná spotreba energie administratívnej budovy:

- $\quad$ v pôvodnom stave: $42937 \mathrm{kWh} /$ rok; 139,36 kWh/m².rok, 
- $\quad$ v obnovenom stave: $19392 \mathrm{kWh} /$ rok; $59,34 \mathrm{kWh} / \mathrm{m}^{2}$.rok.

Pri použití referenčného klimatického roka zohl’adňujúceho zmenu klímy je ročná spotreba energie:

- v pôvodnom stave: $38295 \mathrm{kWh} / \mathrm{rok} ; 124,29 \mathrm{kWh} / \mathrm{m}^{2}$.rok,

- v obnovenom stave: $20665 \mathrm{kWh} ; 63,24 \mathrm{kWh} / \mathrm{m}^{2}$.rok.

Spotreba energie po obnove administratívnej budovy pri uvažovaní súčasných klimatických podmienok klesla v porovnaní so spotrebou energie budovy v pôvodnom stave o 54,8 \%. Pri uvažovaní zmeny klímy bol v pokles spotreby energie o $51,9 \%$ v porovnaní s pôvodným stavom so súčasnými klimatickými podmienkami. Rozdiel spotreby energie obnovenej budovy pri uvažovaní súčasných a budúcich klimatických podmienok je $1273 \mathrm{kWh} /$ rok. Zvýšenie spotreby energie pri zadaní budúcich klimatických údajov spôsobil predovšetkým väčší dopyt po chladení budovy; z pôvodných $3448 \mathrm{kWh} /$ rok pri súčasných klimatických podmienkach na $6126 \mathrm{kWh} /$ rok pri uvažovaní budúcich klimatických podmienok. Naopak spotreba energie na vykurovanie budovy klesla z približne $3230 \mathrm{kWh} /$ rok na $1840 \mathrm{kWh} /$ rok.

Zaujímavým je sledovanie spotreby energie budovy v pôvodnom stave za predpokladu, že by nedošlo k jej obnove. Pri porovnaní spotreby energie pri uvažovaní súčasných a budúcich klimatických podmienok z výsledkov vyplýva, že v období okolo roku 2050 by budova v pôvodnom stave spotrebovala o približne $4640 \mathrm{kWh} / \mathrm{rok}$ menej. Tento pokles možno vysvetlit' najmä zníženým dopytom do vykurovaní z 14764 kWh/rok pri uvažovaní súčasných klimatických podmienok na $10320 \mathrm{kWh} /$ rok pri uvažovaní budúcich klimatických podmienok. Túto je skutočnost' je vo všeobecnosti potrebné zohl'adnit' pri posudzovaní vhodnosti budovy pre obnovenie prostredníctvom EPC projektu, aby projekt priniesol uspokojivé výsledky pre všetky zúčastnené strany.

\section{ZÁVER}

Klimatické zmeny sú dnes vysoko aktuálny a celosvetovo diskutovaný problém. Vzhl’adom na ciel' Európskej únie stat' sa do roku 2050 prvým uhlíkovo neutrálnym kontinentom a fakt, že budovy patria k jedným z najväčších spotrebitel'ov energie, je nevyhnutné pristúpit' $\mathrm{k}$ vlne obnovy budov. EPC projekt ako jedna z možností financovania ponúka možnost' obnovy aj takých budov, na ktorých obnovu nemá majitel' k dispozícii potrebnú výšku investície, t.j. predovšetkým verejné budovy. V súvislosti s tým, článok preukázal zmyselnost’ obnovy existujúcich budov a vplyv klimatických zmien na spotrebu energie v konkrétnej administratívnej budove. Výsledky simulácie jasne ukazujú, že podl’a očakávaní dochádza k nárastu spotreby energie na chladenie a k poklesu spotreby energie na vykurovanie. Možno koštatovat', že energetické simulácie sú vhodným nástrojom na predikciu spotreby energií v budovách v budúcnosti, ked’že dokážu demonštrovat' vplyv klimatických zmien na energetickú hospodárnost' budovy a sú jednou z možností ako zaistit', aby budovy v budúcnosti vedeli spol'ahlivo pracovat' za meniacich sa klimatických podmienok tak, aby vytvárali komfortné prostredie pre svojich užívatel'ov.

\section{Použité zdroje}

[1] Krarti, M.: Energy audit of building systems. An engineering approach. Second edition. Boca Raton, FL: Taylor and Francis Group, 2011. ISBN 978-4398-2872-4.Citace 2

[2] Dias, B., Carrilho ga Graca, J.G., Soares, P.M.M.: Comparison of Methodologies for Generation of Future Weather Data for Building Thermal Energy Simulation. In Energy and Buildings. 2019.

[3] Acciona. Causes of climate change. [online]. Dostupné z: https://www.acciona.com/climate-change/.

[4] IPCC: Climate change 2014: Synthesis report Contribution of working groups I, II and III to the Fifth Assessment report of the Intergovernmental Panel on Climate Change. Geneva, Switzerland, 2014.

[5] Ministerstvo životného prostredia Slovenskej republiky. Stratégia adaptácie Slovenskej republiky na zmenu klímy. 2018.

[6] Európska Komisia. Oznámenie Komisie. Európska zelená dohoda. Brusel, 2019.

[7] Európska Komisia. Ambicióznejšie klimatické ciele pre Európu na rok 2030. Investícia do klimaticky neutrálnej budúcnosti v prospech našich občacov. Brusel, 2020.

[8] European Commission. Financing energy efficiency. [online]. Dostupné z: https://ec.europa.eu/energy/topics/energy-efficiency/financing-energy-

[9] Zákon č.321/2014 Z.z. Zákon o energetickej efektívnosti a o zmene a doplnení niektorých zákonov.

[10] Súčasný stav EPC. [online]. Dostupné z: http://www.apes-sk.eu/sucasny-stav-epc-v-sr/.

[11] Belcher, S. E., Hacker, J.N., Powell, D.S.: Constructing Design Weather Data for Future Climates. In Building Services Engineering Research and Technology. 2005, 49-61.

[12] Cayan, D., Luers, A., Hanemann, M., Franco, G., Hite, W., Aper, P.: Scenarios of climate change in California: An overview. 2021. 